\title{
Shielding Property of Closed-Cell AISi7 Foams and AlSi7 Bulk Materials against Gamma Rays
}

\author{
Arif UZUN ${ }^{1}$, Uğur GÖKMEN ${ }^{2}$, Hanifi ÇiNici ${ }^{3}$, Aslı KURNAZ $^{4}$, Mehmet Atıf ÇETiNER $^{5}$ \\ ${ }^{1}$ Kastamonu University, Faculty of Engineering and Architecture, Department of Mechanical Engineering, Kastamonu. \\ ${ }^{2}$ Gazi University, Technical Sciences Vocational School, Ankara. \\ ${ }^{3}$ Gazi University, Faculty of Technology, Metallurgy and Materials Engineering Department, Ankara. \\ ${ }^{4,5}$ Kastamonu University, Faculty of Arts and Sciences, Department of Physics, Kastamonu. \\ e-posta: auzun@kastamonu.edu.tr
}

Geliş Tarihi: 14.04.2016 ; Kabul Tarihi: 03.11.2016

\begin{tabular}{|c|c|}
\hline & \\
\hline & The aim of this paper is experimental comparison of shielding properties against gamma rays among \\
\hline Al foam; Gamma ray; & closed-cell AlSi7 foams and bulk materials. These materials were produced by powder metallurgy \\
\hline $\begin{array}{l}\text { nielding; Attenuation } \\
\text { coefficient. }\end{array}$ & $\begin{array}{l}\text { method. Gamma rays attenuation measurements were performed at photon energies of } 88,511,662 \text {, } \\
1173,1275 \text { and } 1332.5 \mathrm{keV} \text {. The obtained results revealed that AlSi7 bulk materials offer better gamma } \\
\text { rays attenuation capabilities due to their high density compared to closed-cell AlSi7 foams. }\end{array}$ \\
\hline
\end{tabular}

\section{Kapalı Gözenekli AISi7 Köpükler ve AISi7 Bulk Malzemelerin Gama Işınlarına Karşı Zırhlama Özelliği}

\begin{tabular}{|c|c|}
\hline & Özet \\
\hline $\begin{array}{c}\text { Anahtar kelimeler } \\
\text { Al köpük; Gama ışını; } \\
\text { Zırhlama; Zayıflatma } \\
\text { katsayısı. }\end{array}$ & $\begin{array}{l}\text { Bu çalışmanın amacı kapalı gözenekli AlSi7 köpükler ile AlSi7 bulk malzemelerin gama ışınlarına karşı } \\
\text { zırhlama özelliklerinin deneysel olarak karşılaştırılmasıdır. Bu malzemeler toz metalurjisi yöntemi ile } \\
\text { üretilmiştir. Gama ışınları zayıflatma ölçümleri } 88,511,662,1173,1275 \text { ve } 1332.5 \text { keV foton } \\
\text { enerjilerinde gerçekleştirilmiştir. Elde edilen sonuçlar AlSi7 bulk malzemelerin kapalı gözenekli AISi7 } \\
\text { köpüklere kıyasla daha iyi gama ışını zayıflatma yeterliliğine sahip olduğunu göstermektedir. Bunun } \\
\text { nedeni ise bulk malzemelerin köpüklere kıyasla daha yüksek yoğunluğa sahip olmalarıdır. }\end{array}$ \\
\hline
\end{tabular}

(c) Afyon Kocatepe Üniversites

\section{Introduction}

The expected properties in the materials used in the nuclear field are low weight and good levels of radiation attenuation capability due to new criteria which include protecting against dangerous climate change that may occur around the nuclear power plants and nuclear terrorist attacks, radioactive waste storage and processing facilities (Chen et al. 2014, Corner et al. 2011, Watson and Scott 2009). Earlier there have been several studies on materials such as ceramics, polymers, metals and alloys used for this purpose (Grossbeck, 2012, Hobbs et al. 1994, Katoh et al. 2012). Leonard (2012) presented a detailed review of the irradiated properties database for niobium, tantalum, molybdenum, and tungsten refractory metals and their alloys. For example, martensitic steels are of current interest because of their radiation resistance and low radio activation properties. The irradiation response of the ceramic material is more complicated than metallic materials (Grossbeck, 2012). However, only a few studies have been reported on radiation shielding performance of porous materials.

Today, one of the important porous materials is aluminum foam. Aluminum foams have extremely superior mechanical, physical and acoustic properties (Banhart, 2001). Combination of these properties provides that these structures to be widely used as structural and functional materials in industries such as the automotive, aerospace 
and railway (Aguiree-Perale et al. 2012, Ashby et al. 2000, Banhart, 2001, Degischer and Kriszt 2002, Hangai et al. 2014, Khabushan et al. 2013, Lefebvre et al. 2008). Currently, the most commonly used production methods are solid-gas eutectic solidification, high pressure casting method, powder metallurgy method, and melt-foaming method (Baumaster 1992, Kitazono et al. 2002, Ma and Song 1998, Shiomia et al. 2010). In powder metallurgy method, aluminum foams are made by expansion of foamable precursor in foaming moulds. In a study conducted by Xu et al. (2010) the open cell foam structures filled with water and borided water exhibited excellent performance against neutrons. Neutron sources and nuclear reactors release gamma rays with neutrons. Therefore, it is difficult to determine the behavior of neutron-absorbing material against gamma rays. Both open-cell and closed porous metallic foams provide positive contributions as potential material for radiation shielding applications. In a study conducted by Chen et al. (2014) the attenuation performance against gamma rays and neutrons among aluminum A356, closed-cell and open-cell aluminum foams infiltrated with materials such as borated polyethylene, paraffin wax, water and borated water were compared.

In this study, the experimental comparison of shielding properties against gamma rays among AlSi7 foams and bulk materials which were produced by powder metallurgy were studied. For the investigation of the gamma radiation behavior of these materials, Cd-109, Na-22, Cs-137, Co-60 radioisotopes were used as gamma source in the experimental works. Gamma transmission technique was used for the measurements.

\section{Gamma Rays Measurements}

\subsection{Theory}

Gamma transmission technique is based on the interaction of the material atoms with gamma rays as it passes through materials. Gamma rays lose all or a portion of the energy due to this interaction. Transmission is measured by the radiation intensity passing through the material and coming out of source (Foldiak, 1986). Count value (I) obtained by using different thicknesses of materials is dispensed with the count value $\left(I_{o}\right)$ obtained without the material. Thus, the relative count values $\left(I / I_{o}\right)$ for each material thickness is obtained. For each material, the gamma attenuation curves are generated by drawing thickness-relative count graphs. According to BeerLambert's law, the linear attenuation coefficient $(\mu)$ of materials (Equation 1 ) can be derived from these curves (Knoll, 2010).

$$
I=I_{o} e^{-\mu x}
$$

Where; $I$ and $\mathrm{I}_{\mathrm{o}}$ denote the attenuated and incident gamma ray intensity, respectively, $\mu\left(\mathrm{cm}^{-1}\right)$ is the linear attenuation coefficient and $x(\mathrm{~cm})$ is sample thickness. The mass attenuation coefficient $\left(\mu_{m}\right)$ is obtained through the use of linear attenuation coefficient calculated for the material. It is calculated depending on the material density $(\rho)$ by the formula given in Equation 2 (Knoll, 2010, L'Annunziata, 2007).

$$
\mu_{m}=\mu / \rho
$$

\section{Experimental Procedure}

Closed-cell AISi7 foams and AlSi7 materials used in experimental studies were produced by powder metallurgy method (Uzun and Turker 2015). Figure 1 illustrates the macrostructure images of crosssection of samples. The densities of samples are also presented in Table 1. Gamma ray transmission experiments of samples produced in different thicknesses (5, 12 and $15 \mathrm{~mm}$ ) were performed in vertical beam transmission geometry. Each tests were repeated three times. 


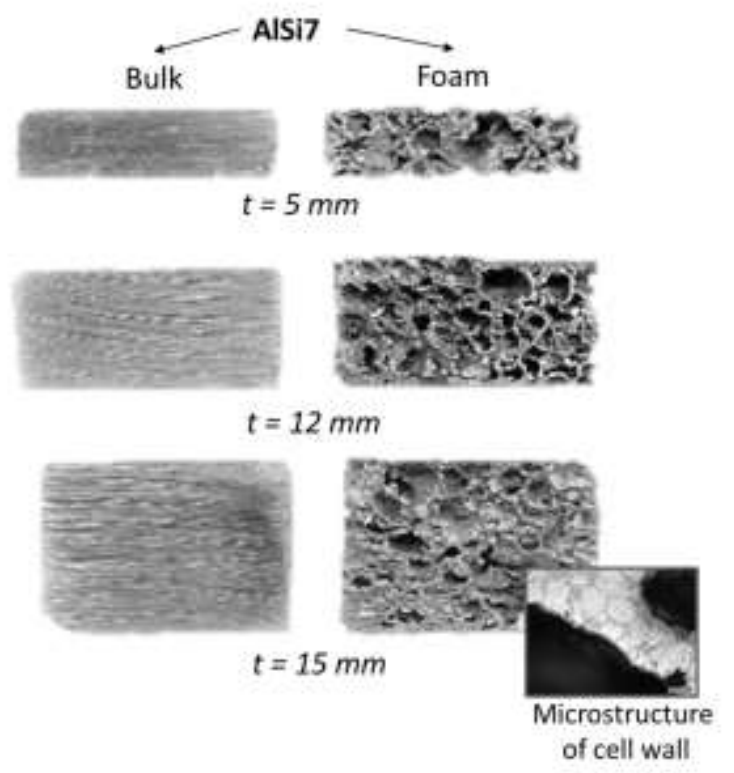

Figure 1. Cross-section of closed-cell AlSi7 foams and bulk materials.

Table 1. Densities of samples.

\begin{tabular}{ccc}
\hline \multirow{2}{*}{ Thickness $(\mathbf{m m})$} & \multicolumn{2}{c}{ Density $\left(\mathrm{g} \cdot \mathrm{cm}^{-3}\right)$} \\
\cline { 2 - 3 } & Foam & Bulk \\
\hline $\mathbf{5}$ & 0.68 & 2.68 \\
\hline $\mathbf{1 2}$ & 0.56 & 2.66 \\
\hline $\mathbf{1 5}$ & 0.53 & 2.63 \\
\hline
\end{tabular}

Gamma detection device is shown schematically in Figure 2. The distance between the radioactive source and the detector is $90 \mathrm{~mm}$. To achieve a narrow parallel beam, the source is positioned using the lead holder with a hole diameter of 2 $\mathrm{mm}$. Samples were placed on collimator at $80 \mathrm{~mm}$ distance from the source. Then the photon flux is transported to the detector by passing from the lead holder. Gamma radiation transmission was measured using Nal(Tl) detector. Each sample was measured by photon energies of $88,511,662$, 1173,1275 and $1332.5 \mathrm{keV}$.

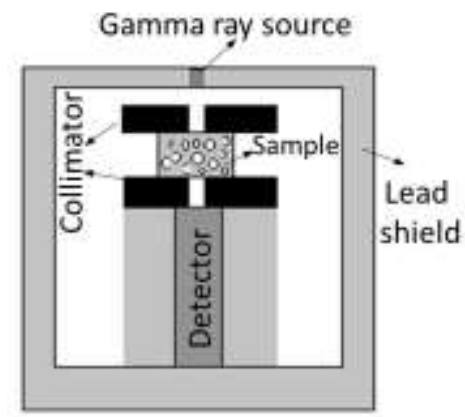

Figure 2. Schematic diagram of gamma spectrometry system

\section{Results and Discussion}

The transmission values of three samples with different thicknesses at six different photon energies are shown in Figure 3. As shown in the graphs, the transmission values decreased with increase in sample thickness. Transmission in the same kind of samples under all sources (energies) is similar slope. It is clear that the bulk materials have better absorbing and radiation attenuation characteristics due to their high density compared to foams. Chen et al. (2014) observed that closedcell foams demonstrate an effective shielding property compared to bulk aluminum for energies below $0.662 \mathrm{MeV}$. However, researchers infiltrated in close-cell and open-cell foams variety of second phase materials. An increased attenuation of 2, 6, and $10 \%$ can be observed at a lower energy of 88 $\mathrm{keV}$ in foam materials with thickness of 5, 12 and $15 \mathrm{~mm}$, respectively. However, the bulk materials with same thickness were attenuated about 14, 31 and $40 \%$ at a lower energy of $88 \mathrm{keV}$. The slope of the transmission curve of the bulk and foam materials is quite different. This condition is related to the density and structural qualities of the materials (Mavi et al. 2014). 

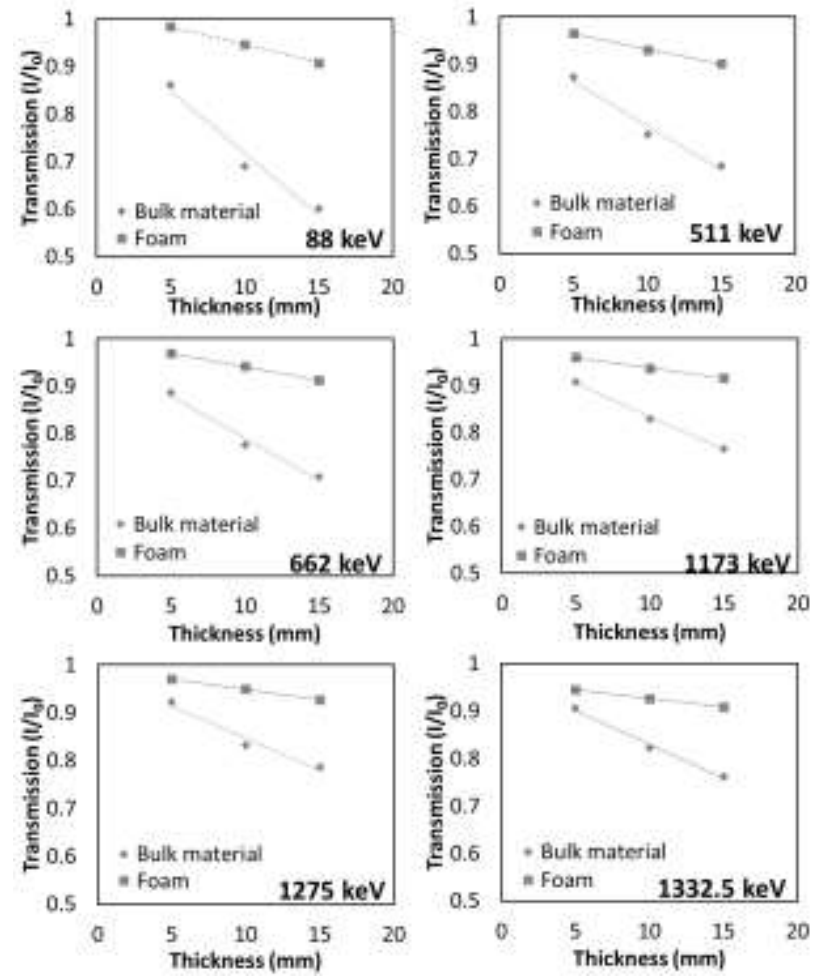

Figure 3. Attenuation of bulk and foam samples at six different photon energies

For AlSi7 samples, the mass attenuation coefficient obtained experimentally was decreased due to the increase in photon energy as seen in Table 2. Initially, the mass attenuation coefficient had a maximum value, and then it decreased. But, a similar situation is difficult to say for AlSi7 foams. Because they have non-homogeneous pore structure, their mass attenuation coefficient is a complex correlation. It is also observed that the mass attenuation coefficient of aluminum foam is slightly higher than that of the bulk material for energies above $88 \mathrm{keV}$. According to the study by Gedik and Baytas (2015), the linear attenuation coefficient and porosity of the foams was nonuniform locally.
Table 2: Experimental values of mass attenuation coefficients $\left(\mathrm{cm}^{2} / \mathrm{g}\right)$ for aluminium foams and bulk materials

\begin{tabular}{|c|c|c|c|}
\hline \multirow[t]{2}{*}{$\begin{array}{c}\text { Energy(keV) } \\
\text { (Experimental) }\end{array}$} & \multirow[t]{2}{*}{$\begin{array}{l}\text { Thickness } \\
\text { (mm) }\end{array}$} & \multicolumn{2}{|c|}{$\begin{array}{l}\text { Mass attenuation } \\
\text { coefficients }\left(\mathrm{cm}^{2} / \mathrm{g}\right)\end{array}$} \\
\hline & & $\begin{array}{l}\text { AlSi7 } \\
\text { bulk }\end{array}$ & $\begin{array}{l}\text { AlSi7 } \\
\text { foam }\end{array}$ \\
\hline \multirow[t]{3}{*}{88} & 5 & 0.111 & 0.047 \\
\hline & 12 & 0.116 & 0.081 \\
\hline & 15 & 0.128 & 0.122 \\
\hline \multirow[t]{3}{*}{511} & 5 & 0.101 & 0.106 \\
\hline & 12 & 0.090 & 0.108 \\
\hline & 15 & 0.096 & 0.165 \\
\hline \multirow[t]{3}{*}{662} & 5 & 0.090 & 0.094 \\
\hline & 12 & 0.080 & 0.089 \\
\hline & 15 & 0.087 & 0.116 \\
\hline \multirow[t]{3}{*}{1173} & 5 & 0.072 & 0.119 \\
\hline & 12 & 0.059 & 0.098 \\
\hline & 15 & 0.068 & 0.110 \\
\hline \multirow[t]{3}{*}{1275} & 5 & 0.061 & 0.089 \\
\hline & 12 & 0.058 & 0.078 \\
\hline & 15 & 0.061 & 0.095 \\
\hline \multirow[t]{3}{*}{1332.5} & 5 & 0.074 & 0.141 \\
\hline & 12 & 0.061 & 0.114 \\
\hline & 15 & 0.069 & 0.121 \\
\hline
\end{tabular}

\section{Conclusion}

In this study, gamma rays shielding properties of AlSi7 bulk materials and closed-cell foams were investigated using $\mathrm{Cd}-109, \mathrm{Na}-22, \mathrm{Cs}-137$, Co 60 radioisotopes. Bulk materials have shown a clearly advantageous behavior, when comparing gamma attenuation against the same thickness of foam materials because, the bulk materials have a higher density compared to aluminum foams. The bulk materials with same thickness were 
attenuated about 14,31 and $40 \%$ at a lower energy of $88 \mathrm{keV}$. However, the mass attenuation coefficient of aluminum foam is slightly higher than that of the bulk material for energies above $88 \mathrm{keV}$. This condition is related to the density and structural qualities of the materials.

\section{References}

Aguirre-Perales, L. Y., Jung, I. H. and Drew, R. A., 2012. Foaming behavior of powder metallurgical Al-Sn foams. Acta Materialia, 60, 759-769.

Ashby, M. F., Evans, T., Fleck, N. A., Hutchinson, J. W., Wadley, H. N. G. and Gibson, L. J., 2000. Metal Foams: A Design Guide: A Design Guide. Elsevier.

Banhart, J., 2001. Manufacture, characterisation and application of cellular metals and metal foams. Progress in materials science, 46, 559-632.

Baumeister, J. and Schrader, H., 1992. U.S. Patent No. 5,151,246. Washington, DC: U.S. Patent and Trademark Office.

Chen, S., Bourham, M. and Rabiei, A., 2014. Novel lightweight materials for shielding gamma ray. Radiation physics and chemistry, 96, 27-37.

Corner, A., Venables, D., Spence, A., Poortinga, W., Demski, C. and Pidgeon, N., 2011. Nuclear power, climate change and energy security: exploring British public attitudes. Energy Policy, 39, 4823-4833.

Degischer, H. P. and Kriszt, B., 2002. Handbook of cellular metals. Weinheim: Wiley-vch.

Foldiak, G., 1986. Industrial application of radioisotopes. 1st ed. Elsevier Science Ltd, Amsterdam, Netherland.

Gedik, S. and Baytaş, A. F., 2015. Shielding of Gamma Radiation by Using Porous Materials. Acta Physica Polonica, A., 128

Grossbeck M.L., 2012. Effect of radiation on strength and ductility of metals and alloys, Comprehensive Nuclear Materials, 1, 99-122.

Hangai, Y., Saito, K., Utsunomiya, T., Kuwazuru, O. and Yoshikawa, N., 2014. Fabrication and compression properties of functionally graded foam with uniform pore structures consisting of dissimilar A1050 and A6061 aluminum alloys. Materials Science and Engineering: A, 613, 163-170.

Hobbs, L. W., Clinard, F. W., Zinkle, S. J. and Ewing, R. C., 1994. Radiation effects in ceramics. Journal of Nuclear Materials, 216, 291-321.

Katoh, Y., Snead, L. L., Szlufarska, I. and Weber, W. J., 2012. Radiation effects in SiC for nuclear structural applications. Current Opinion in Solid State and Materials Science, 16, 143-152.
Khabushan, J. K., Bonabi, S. B., Aghbagh, F. M. and Khabushan, A. K., 2014. A study of fabricating and compressive properties of cellular Al-Si (355.0) foam using $\mathrm{TiH}_{2}$. Materials and Design, 55, 792-797.

Kitazono, K., Kitajima, A., Sato, E., Matsushita, J. and Kuribayashi, K., 2002. Solid-state diffusion bonding of closed-cell aluminum foams. Materials Science and Engineering: $A, 327,128-132$.

Knoll, G. F., 2010. Radiation detection and measurement. John Wiley \& Sons.

L'Annunziata, M. F., 2007. Radioactivity: introduction and history. Elsevier.

Lefebvre, L. P., Banhart, J. and Dunand, D., 2008. Porous metals and metallic foams: current status and recent developments. Advanced Engineering Materials, 10, 775-787.

Ma, L. and Song, Z., 1998. Cellular structure control of aluminium foams during foaming process of aluminium melt. Scripta Materialia, 39, 1523-1528.

Mavi, B., Gurbuz, F., Ciftci, H. and Akkurt, I., 2014. Shielding property of natural biomass against gamma rays. International journal of phytoremediation, 16, 247-256.

Shiomi, M., Imagama, S., Osakada, K. and Matsumoto, R., 2010. Fabrication of aluminium foams from powder by hot extrusion and foaming. Journal of Materials Processing Technology, 210, 1203-1208.

Uzun, A. and Turker, M., 2015. The investigation of mechanical properties of $\mathrm{B}_{4} \mathrm{C}$-reinforced $\mathrm{AlSi} 7$ foams. International Journal of Materials Research, 106, 970-977.

Watson, J. and Scott, A., 2009. New nuclear power in the UK: A strategy for energy security?. Energy Policy, 37, 5094-5104.

Xu, S., Bourham, M. and Rabiei, A., 2010. A novel ultralight structure for radiation shielding. Materials and Design, 31, 2140-2146. 